\title{
African American Males Educational Success Factors
}

\author{
Michael Brooks ${ }^{1}$, Christopher Jones ${ }^{2} \&$ Jessie Latten $^{2}$ \\ ${ }^{1}$ Counselor Education, North Carolina A\&T State University, United States \\ ${ }^{2}$ University of Alabama at Birmingham, United States \\ Correspondence: Michael Brooks, Counselor Education, North Carolina A\&T State University, United States
}

\author{
Received: November 9, 2013 Accepted: November 20, 2014 Available online: February 17, 2014 \\ doi:10.11114/ijsss.v2i2.273 URL: http://dx.doi.org/10.11114/ijsss.v2i2.273
}

\begin{abstract}
Due to the recent call for educators to increase African American educational achievement (Butler, 2012; Toldson, Sutton, \& Brown, 2012; Harris \& Taylor, 2012), the authors sought to identify personal characteristics associated with African American male educational success. There appears to be little discussion about this group's success in today's academic literature (Harper, 2009b). Thirty high-achieving African American male undergraduate students between the ages of 18 and 22 at an urban southeastern American university were surveyed. Participants completed Likert scale and open-response items regarding their success in college. The results suggest high achieving African-American males deem sources of inspiration, people, and financial incentives as important for educational success. Also, a significant difference was discovered between STEM (science, technology, engineering, or math) majors and non-STEM majors with regards to age, paternal relationship, and incentives (internal, external) to achieve goals. Implications for administrators and higher education were discussed.
\end{abstract}

Keywords: academic success, success factors

\section{Factors Associated with Educational Success of African American Males}

Promoting the academic success of all students is an ongoing agenda item for educators, citizens, and politicians (Cuyjet, 2006). In addition, American schools, colleges, and universities continue to increase in the diversity of their students, reflecting a changing American culture in which a homogeneous majority is becoming less dominant (Anderson, 2003). These demographic changes have forced educators to examine the academic success of diverse student populations.

Recent educational statistics report a continuing disparity between the academic success of students of color and white students (National Center for Education Statistics [NCES], 2012). Comparative studies focused on explanations for the poor academic performance of students of color (Weigher \& Tedin 2006; Steele, 2003; Anaya \& Cole 2001) rather than the success aspects of those high achieving students within this group (Brooks, Jones, \& Burt 2012). In an effort to recruit and retain these students at colleges and universities, characteristics of successful underrepresented students, in particular black male students, need to be better understood (Butler-Barnes, Williams, and Chavous, 2012). The ensuing study will attempt to address the above concern and provide findings to assist practitioners, researchers, and administrators in their effort to support African American male students at their institutions.

\section{Achievement Gap}

The U.S. population continues to change and become more culturally and ethnically diverse (Shrestha, 2011) and (DW Sue, D. Sue 2012). The United States Census Bureau (2012) projects by 2043, the United States will be a majority-minority country. Even with this growing demographic change, there continues to be an academic achievement gap between whites and more culturally diverse populations within the United States, particularly black and Hispanic males (Harper and Harris, 2012). More students of color than white students dropped out in 2010. The disparity between the academic success of minority and white students continues in post-secondary schools. The percentage of degrees conferred by race (Table 1) illustrates the continued academic achievement gap based on the latest percentages of degrees conferred in the United States. 
Table 1. Percentage of Degrees Conferred By Race 2009-2010

\begin{tabular}{llllll}
\hline Degree Obtained & White & Black & Hispanic & Asian & American Indian \\
\hline Bachelor's Degrees & $72.9 \%$ & $10.3 \%$ & $8.8 \%$ & $7.3 \%$ & $0.8 \%$ \\
Master's Degree & $72.8 \%$ & $12.5 \%$ & $7.1 \%$ & $7.0 \%$ & $0.6 \%$ \\
Doctorate Degrees & $74.3 \%$ & $7.4 \%$ & $5.8 \%$ & $11.8 \%$ & $0.7 \%$ \\
\hline
\end{tabular}

\section{Educational Success Characteristics for Students of Color}

In an effort to provide high-quality primary and secondary education to students from diverse cultural backgrounds, it is essential to examine characteristics associated with academic success in this population. Previous research on contributors to the educational success of students of color examined internal dynamics, as well as external or environmental influences (Saenz, Hurtado, Barrera, Walf, \& Yeung, (2007). Students of color who participate in more rigorous academic high school curriculums achieve higher rates of student success (Anderson \& Kim, 2006). Research has also shown students who grew up in homes where they were challenged and education was valued by their parents, were motivated and successful academically (Dennis, Phinney, \& Chuateco 2005; Harper, 2012; Palmer \& Gasman, 2008). Even though a supportive and academically challenging environment is important to academic success, many other external reasons contribute to these students' success. Many African American students, particularly males, attribute their motivation to the need to their sense of understanding what a college degree can do for them financially (John, Hu, Simmons, Carter, \& Weber, 2004). African American male students have been shown to enter college with the aspirations to entering a major directly correlated with higher incomes, such as engineering (Harper, Carini, Bridges, \& Hayek 2004). These successful students have demonstrated other elements which have been symmetrical to their overall success.

Academically successful black undergraduates have reported internal features such as resilience, having a hopeful spirit, and a strong sense of self-efficacy (Harper, 2009a). Achievement motivation is often the greatest predictor for GPA (Robinson, Lauver, Le, Davis, Langley, \& Carlstrom, 2004). Many high achieving African American students attribute their academic success to their internal motivation (Bonner, 2010).

Fries-Britt \& Griffin (2007) conducted a qualitative study with 9 high achieving African American college students between the ages of 19 and 23. All participants were full-time students and were products of both public and private K-12 education. Participants completed both a questionnaire, as well as participated in interviews. The outcomes of this study displayed various sources to the overall academic success of these students. One such theme to emerge was the intrinsic motivation to dispel myths concerning African American educational success. These students were motivated by their need to show their campus community African Americans are intelligent and capable people (Fries-Britt \& Griffin, 2007). Students of color who failed to create a sense of intrinsic motivation lowered the expectations placed on themselves within the classroom (Strayhorn, 2008). Evaluating internal and external attributes, within students was essential in analyzing academic success.

Developmentally, supportive relationships with adults, participation in community youth programs, academic success, pro-social skills training, and communication of high expectations to youth are common leitmotifs which appear to be related to minority youth's academic success (Palmer \& Gasman, 2008; Palmer \& Young, 2009; Strayhorn, 2008). Participation in university enrichment programs was also noted as helpful because of the early exposure to higher education. Mentoring programs, for example, particularly for African American male students has provided aid to them; specifically in adjusting to college (Brooks et al. 2012). Highlighting personal characteristics manifested in the various experiences by high achieving students is the focus of this study.

For the purpose of this study, a "high achieving" student was operationally defined as a student with a minimum 3.0 cumulative college grade point average (GPA), and enrolled as a full-time student (minimum 12 semester hours) at the 4-year urban university in the southeast United States for a minimum of two semesters. The first author of this study directed a recruitment and retention mentoring program, designed for African American male students. As director, there were ample opportunities to interact with African American male students who are doing exceptionally well in college. The overall mission of this program was (and still is) to retain these students at the university by providing them with information vital to their success. Discussion topics such as how to develop time management skills, navigating the college classroom, and building positive relationships on campus are a few of the subjects covered. The primary methods for achieving student retention were peer mentoring and the development of specific program activities; these approaches provide assistance in collegiate academic and social adjustment (Harper, 2012).

The purpose of this study was to identify personal characteristics associated with high achieving African American males. The following research questions were investigated: 
1. What are the personal characteristics associated with high achieving African-American male students' educational success?

2. Are there differences in the personal characteristics associated with high achieving African-American males students' educational success for stem majors and non-stem majors?

\section{Method}

\subsection{Peer Mentoring Program}

Participants were recruited from a peer-mentoring program designed to support African American male college students at an urban university in the southeast United States; all African American male first semester freshmen were eligible to join this particular program. Students were recruited into this program upon their acceptance into the university. The program participants represented approximately $43 \%$ of the total African American male population on campus. Thirty percent of the other African American males on campus, who chose not to participate in this program, were athletes. The remaining $27 \%$ of the African American male students on campus were non-athletes and non-program participants. Participation in the program was completely voluntary. Therefore those (27\%) African American male students who were non-program participants were eligible, but simply chose not to be program members.

Out of 230 students in the mentoring program, 59 met the necessary criteria for inclusion in the study. The criteria for this study included being an African American male between the ages of 18 and 22, "high achieving", and enrolled in at least their third semester of college. The 59 students were extended an opportunity to participate; of those fifty-nine, 30 returned completed informed consent forms and questionnaires. These student classifications ranged from 2nd year or sophomore year, to 4th year or seniors. There were no participants who were beyond their 4th year of college.

\subsection{Measures}

Data was collected using the Multidimensional Scale of Perceived Social Support (MSPSS; Zimet, Dahlem, Zimet \& Farley, 1988). The MSPSS is a 12-item self-report measure which assesses perception and adequacies of social support from friends, family, and significant others. Participants rated their agreement with items on each of three subscales, via a 7-point Likert-type scale from (1) very strongly disagree to (7) very strongly agree. Total and subscale scores were calculated by averaging responses, and can therefore range from 1 to 7 . Higher scores were indicative of more perceived social support.

In addition to the MSPSS, A five point Likert-type questionnaire was also administered. This questionnaire was developed by Clark, Shreve, and Stone (2004) for the purposes of determining the success characteristics of minority students. Clark, Shreve, and Stone, (2004) used the instrument to examine the characteristics of successful minority students which had successfully navigated their undergraduate experience and entered graduate school. The questionnaire was based on areas inclusive of personal characteristics, sources of inspiration, important events/milestones, and financial incentives. The instrument also asks demographic information (age, classification, major, parent education and family income), and open-ended questions to obtain detailed individual insights. The open-ended questions asked participants about decision-making style, locus of control, orientation toward the future, family dynamics, personal and cultural values, incentives, resources (internal and external), current aspirations, and selected major.

\subsection{Procedure}

After obtaining IRB approval, participants were invited and selected from the peer-mentoring program discussed earlier. It took participants between 20-40 minutes to complete the questionnaire. Participants completed questionnaires in person at the institution where the study was conducted.

\subsection{Coding}

Section I of the MSPSS requested demographic information. The participant's responses were recorded directly from the MSPSS. Participant's departments and majors were coded as 1 for STEM majors and 2 for non-STEM. The variable County, State (CS) represented participants' hometowns and was coded according to ACES geographical regions (Association of Counselor Education and Supervision, 2010); 1 was coded for Southern, 2 for North Atlantic, 3 for North Central, and 4 was used for to combine the Rocky Mountain and Western regions.

Section II of MSPSS contained a five point Likert scale from 1 (unimportant) to 5 (very important). In section II of the MSPSS participants were asked to rate their personal characteristics (inner resources), sources of inspiration, mentors/relationships, and financial incentives.

Qualitative items on the MSPSS such as those in section II number 4 and Section III consisted of interview type questions which elicited open-ended responses. Participant's responses from these sections of the MSPSS were read by investigators and categorized into two groups. If participants indicated they took initiative and did not wait for things to 
happen, then they were categorized and coded into group one. If participants indicated they were passive and just let things happen, they were categorized and coded into group two. If participants' response contained elements from both categories then they were coded group 3.

\section{Results}

The purpose of this study was to identify personal characteristics associated with high achieving African American males. To answer the first research question, descriptive statistics were calculated. A summation of the demographical information is presented in Table 2. In regards to the personal characteristics associated with high achieving African-American male students', a report of the participant's responses is presented in Table 3.

Table 2. Demographic Descriptive Statistics

\begin{tabular}{lll}
\hline Characteristics of Participants & Frequencies & Percentages \\
\hline Total Participants & 30 & 100 \\
Age & & \\
19 & 5 & 16.7 \\
20 & 19 & 63.3 \\
21 & 6 & 20.0
\end{tabular}

Years in College

$\begin{array}{llr}\text { (1) First Year } & 23 & 53.3 \\ \text { (2) Second } & 4 & 46.7 \\ \text { (5) Other } & 3 & 10.0\end{array}$

Department/Major

(1) Science Majors

(2) Non-Science Majors

County/State

1 Southeast

3 Midwest

Missing

Number of places lived

Job Career of Mother

(1) Management/Professional 19

(3) Sales/Clerical

(4) Production/Transportation

(5) Service/Fast-food

Job Career of Father

(1) Management/Professional

(2) Construction/Maintenance 
Table 3. Ratings of importance of characteristics for educational success

Characteristics

Personal Characteristics (Hope)

(5) Very Important

(4) Important

8

(3) Somewhat Important

(2) Not that Important

(1) Unimportant

Missing

Personal Characteristics (Imagination)

(5) Very Important

(4) Important

(3) Somewhat Important

(2) Not that Important

(1) Unimportant

Missing

Personal Characteristics (Perseverance/Determination)

(5) Very Important

(4) Important

(3) Somewhat Important

(2) Not that Important

(1) Unimportant

Missing

Personal Characteristics (Belief in self and abilities)

(5) Very Important

(4) Important

(3) Somewhat Important

(2) Not that Important

(1) Unimportant

Missing

Sources of Inspiration (Spirituality)

(5) Very Important

(4) Important

(3) Somewhat Important

(2) Not that Important

(1) Unimportant

Missing

Sources of Inspiration (The Media)

(5) Very Important

(4) Important

(3) Somewhat Important

(2) Not that Important

(1) Unimportant

Missing

People (Mother)

(5) Very Important

(4) Important

(3) Somewhat Important
66.7

Percentage

6.7

6.7

0.0 
(2) Not that Important

(1) Unimportant

Missing

People (Father)

(5) Very Important 15

50.0

(4) Important

(3) Somewhat Important

13.3

(2) Not that Important

6.7

(1) Unimportant

10.0

Missing

Financial Incentive (Scholarships/Fellowships)

(5) Very Important

50.0

(4) Important

(3) Somewhat Important

(2) Not that Important

(1) Unimportant

Missing

Financial Incentive (Future Salary)

(5) Very Important 22

(4) Important

13.3

(3) Somewhat Important

(2) Not that Important

(1) Unimportant

Missing

Section II Question 4. (a) (Important events/mile stones)

(1) Graduation from High School

(2) External help (parents or others)

Section II Question 4. (b) (Important Events/Mile Stones)

(1) Acceptance to College 16

(2) External intervention (Parents or Others)

Section III Question 1. (Personal Characteristics)

(1) Perseverance/Tenacity $=1 \quad 24$

(2) Hope/Spirituality $=2 \quad 2$

(3) Both (1 and 2) 2

Missing

Section III Question 2. (Defining Moments of Motivation))

(1) Self Insight/Epiphany $=1$

(2) An External Event/Influence = 2

6.7

(3) Both (1 and 2)

Section III Question 3. (Sources of Inspiration)

(1) Financial/External Sources $=1$

(2) Personal/Internal Sources) $=2$

(3) Both (1 and 2) 
Section III Question 5. (Childhood Hopes and Dreams)

(1) Dreams of professional Achievement $=1 \quad 23$

(2) Dreams of non-professional Achievement $=2 \quad 4$

(3) Both (1 and 2)

Section III Question 6. (How Decisions are made)

$\begin{array}{ll}\text { (1) Painful Decisions } & 13 \\ \text { (2) Intuitive Decisions } & 4 \\ \text { (3) Looking at Alternatives } & 8 \\ \text { (4) Dependent vs Independent Decisions } & 3 \\ \text { Missing } & 2\end{array}$

Section III Question 7. (Locus of Control)

$\begin{array}{ll}\text { (1) Internal LOC } & 24 \\ \text { (2) External LOC } & 4 \\ \text { (3) Both (1 and 2) } & 1 \\ \text { Missing } & 1\end{array}$

Section III Question 8. (Childhood Attitudes towards Future)
(1) Positive
(3) Both (1 and 2)
Missing

Section III Question 9. (Perception of Role in the Family)
(1) Active Role
(2) Negative

Section III Question 10. (The Importance of Values)

$\begin{array}{ll}\text { (1) Personal Values } & 20 \\ \text { (2) Cultural Values } & 2 \\ \text { (3) Both (1 and 2) } & 6 \\ \text { Missing } & 2\end{array}$

Section III Question 13. (Message for a Childlike Yourself)
(1) Positive Message

Section III Question 14. (Would You Change Anything About Your Past?)
(1) Yes

Section III Question 15. (Current Aspirations/Goals)
(1) Career Focused Goals
(2) Personal Focused Goals
(3) Both (1 and 2)

Section III Question 16. (Your Reason for Choosing Your Career)

\begin{tabular}{lll} 
(1) Personal Choice & 23 & 76.7 \\
(2) Choice Influenced by Others & 2 & 6.7 \\
(3) Both (1 and 2) & 2 & 6.7 \\
Missing & 3 & 10.0 \\
\hline
\end{tabular}


In order to investigate the second research question, are there difference in the personal characteristics associated with high achieving African-American males students' educational success for stem majors and non-stem majors? A Mann-Whitney U test was conducted. The Mann-Whitney $\mathrm{U}$ test is an alternative test to the independent sample t-test. The Mann-Whitney $U$ test is used to compare differences between two independent groups when the dependent variable is either ordinal or continuous, but not normally distributed.. It can be used also when the sample sizes are unequal (Maxwell \& Delaney, 2004).

The results of the test indicated that the age of participants who were STEM majors $(M d n=20.00 /$ mean rank $=12.03)$ was significantly lower than the age of participants who were NON-STEM majors $(M d n=20.00 /$ mean rank $=19.46)$, $U=56.5, p<.007, r=.49$ (see Table 4). Participants who were STEM majors $(M d n=5.00 /$ mean rank $=18.03$ ) rated the importance of their relationship with their fathers significantly higher than participants who were NON-STEM majors $(M d n=4.00 /$ mean rank $=11.27), U=55.5, p<.021, r .43$ (see Table 5).Also, the results of the Mann-Whitney $\mathrm{U}$ test for incentives (internal $=$ lower scores, external $=$ higher scores) to achieve goals indicated that participants who were STEM majors $(M d n=2.00 /$ mean rank $=16.47)$ preferred more external incentives than participants who were NON-STEM majors $(M d n=2.00 /$ mean rank $=10.92), U=53.0, p<.047, r=.38$ (see Table 6).

Table 4. Comparison of the Age of Science Majors and Non-Science Majors

\begin{tabular}{lll}
\hline Department/Majors & Mean Rank Scores & $U(2$-tail $)$ \\
\hline STEM majors & 12.03 & $56.50^{*}$ \\
NON-STEM majors & 19.46 & \\
\hline
\end{tabular}
$* p<.05$

Table 5. Comparison of the Importance of Paternal relationships for Science Majors and Non-Science Majors

\begin{tabular}{lll}
\hline Department/Majors & Mean Rank Scores & $U(2$-tail $)$ \\
\hline STEM majors & 18.03 & $55.50^{*}$ \\
NON-STEM majors & 11.27 & \\
\hline
\end{tabular}
$* p<.05$

Table 6. Comparison of Incentives to Achieve Goals for Science Majors and Non-Science Majors

\begin{tabular}{lll}
\hline Department/Majors & Mean Rank Scores & $U(2$-tail $)$ \\
\hline STEM majors & 16.47 & $53.00^{*}$ \\
NON-STEM majors & 10.92 & \\
\hline
\end{tabular}
$* p<.05$

\section{Discussion}

The aim of this study was to detect special individualities linked to high achieving at African American male educational success. Based on the results, it is reasonable to conclude the following. Students within STEM majors were motivated to achieve academically, because they associate academic success with financial success. Many African-American students are equally intrinsically motivated as their white counterparts, but they often are more externally motivated than their White counterparts (Cokley, 2003). It is possible a large percentage of Black male students in this study are driven by financial and tangible outcomes which often come with having a degree in high demand. Black male students with career aspirations such as engineering, business, and medical professions sought out STEM majors because of the potential to earn higher incomes. Recruitment administrators should emphasize career opportunities and benefits, which come with gaining a college degree to prospective Black male students, especially those students who show strong ability with the STEM fields.

The results from the current study also revealed significant intrinsic motivation of high achieving students not in the STEM fields. Participants within this group frequently listed personal sources of inspiration to strive academically. These characteristics included personal achievement goals such as being the first one in their family to finish college. A possible explanation could be intrinsic motivation and goals are often needed to overcome external barriers such as poverty and institutional racism, which have historically impeded the academic progress of African Americans. Previous research revealed students who learned to personally value academic success, have often overcome these and other external factors (Fries-Britt \& Griffin, 2007; Steel \&Aronson, 2004; Strayhorn, 2010). Students who regard themselves as determined have the perseverance, which is needed to be a successful college student (Clark, Shreve, and Stone, 2006).

The study's findings thirdly suggest many of the participants were academically impacted by their relationship with a male role model within their household, specifically those participants within a STEM major. As African-American children are being educated, it is important for them to be raised in families with high levels of parental academic 
engagement (Maton \& Hrabowski, 2004). Even more importantly, they should be exposed to other Black professionals who have benefitted from educational attainment. Black male students with positive black male family members have been shown to have high levels of academic attainment (Butler, Evans, Brooks, Williams, \& Bailey, 2013).

Lastly, the results revealed students involved in STEM majors were younger than those students involved in non-STEM majors. This finding reflects the lower number of students who persist within the STEM as the curriculum becomes increasingly more challenging. Many support programs have a focus to support students within their first year of coursework, but the lower number of older black male students within the study suggests many of those students do not continue far along into their curriculum. Academic support such as concentrated tutoring, curriculum advisement, and continued emotional supported is need to adequately ensure students being successful within the STEM fields. Black male retention and support programs should concentrate more effort into supporting their participants beyond their first year (Butler, Evans, Brooks, Williams, \& Bailey, 2013).

There were limitations to this study identified by the researchers. First, the sample was specifically confined to African American male high achieving students attending school at one university in the southeast. The findings from this study may be difficult to generalize to African American male students in other parts of the United States, to women, or to other races or ethnicities. As all participants in this study are currently receiving mentorship through the on-campus recruitment and retention program, their responses on certain items regarding supportive environments may be skewed in comparison to students on campuses without such a program. Equally so, high achieving African American male students may not choose to be a part of such programs if they do exist. Such students may be stronger self-starters, or simply do not have the time to commit. Many non-program participants receive some these same or similar services collectively, in other programs. The overall low number of participants is the third and last limitation; there were restrictions on the statistical analysis. Participant numbers were low due to students not wishing to give consent to the study, or they were not members of the recruitment/mentoring program. Not having a large participant group may be a reflection on a host of societal and systemic issues. African American male undergraduate students do not make up the majority of student populations at most college campuses. To obtain a more sizable sample, it may be wise to use the African American males who attend several universities. A larger sample size would have been more representative of this population and the findings more trustworthy. However, investigators reported robust statistical significance, which suggest the findings were not produced by random chance.

Overall, the results of this study offer some insight on characteristics strongly associated with African-American male student success. These results have implications for higher education administrators, faculty, and staff, which seek to recruit and retain black male college students on their campus. In addition to providing need-based financial aid, administrators must also provide a career-focused curriculum for African-American males who, according to this study, associate academic achievement with economic success. Future researchers who have interests in African American male success characteristics should consider the current data and examine the findings of this study with a qualitative analysis. Impending inquiries could possibly address those significant variables extracted from this current study. One suggestion would be conducting an emerging thematic analysis involving selected, common short answers from the MSPSS. There are few researchers who have conducted mixed method designs, where the qualitative results complement and support the quantitative, when investigating this population. Mixed method design can be used to compensate for the shortcomings in quantitative and qualitative research (Hurtado, et al., 2011).

In sum, the college experience of students of color, African American male students in particular, remains one of the focuses being addressed by colleges and universities within the United States. There are students who come from interesting and obscure backgrounds and situations; however, these students manage to defy odds as they achieve success in college. In a world where African American Males enroll as freshmen, and less than (33.1\%) matriculate and graduate, these young charges tend to finish the undergraduate experience with honors (U. S. Department of Education, 2011). This study has shown that these successful students have personality beliefs and characteristics which parallel their major areas of study and academic practices. It is not known how they acquire these beliefs, but those who are able to create associations with educational triumph, increases diversity throughout the classifications and subsequently larger graduating classes. It is only reasonable and sensible for educators of higher institutions to be culturally responsive and intrigued when communicating about ways to ignite and cultivate such students and directly influence our communities.

\section{References}

Anaya, G., \& Cole, D. G. (2001). Latina/o student achievement: Exploring the influence of student-faculty interactions on college grades. Journal of college student development, 42(1), 3-14.

Anderson, E. L. (2003). Changing US demographics and American higher education. New Directions for Higher Education, 2003(121), 3-12. http://dx.doi.org/10.1002/he.97 
Anderson, E. L., \& Kim, D. (2006). Increasing the success of minority students in science and technology (No. 4). Washington, DC: American Council on Education.

Association for Counselor Education and Supervision. (2010). ACES Regions. Retrieved February 6, 2013, from acesonline: http://www.acesonline.net/about-aces/regions/

Bonner II, F. A. (2010). Academically gifted African American male college students. Santa Barbara, CA: Praeger

Brooks, M., Jones, C., \& Burt, I. (2012). Are African-American Male Undergraduate Retention Programs Successful? An Evaluation of an Undergraduate African-American Male Retention Program. Journal of African American Studies, 1-16.

Butler, S. K. (2012). African American Male Students and the Achievement Gap: Building a Successful. Interamerican Journal of Psychology, 45(2).

Butler, K., Evans, M., Brooks, M., Williams, C., \& Bailey, D. (2013). Mentoring African American men during their postsecondary and graduate school experiences: Implications for the counseling profession. Journal of Counseling and Development, 91, 419-427. http://dx.doi.org/10.1002/j.1556-6676.2013.00113.x

Butler-Barnes, S. T., Williams, T. T., \& Chavous, T. M. (2012). Racial pride and religiosity among African American boys: Implications for academic motivation and achievement. Journal of youth and adolescence, 41(4), 486-498. http://dx.doi.org/10.1007/s10964-011-9675-1

Chronicle of Higher Education. (2008). Low pay for History Ph.D.'s Retrieved 1/30/13, 2013, from http://chronicle.com.fetch.mhsl.uab.edu

Clark, M. A., Shreve, K., \& Stone, C. B. (2004). Taking stock in children: Collaborating to promote success for low income secondary students. NASSP Bulletin. http://dx.doi.org/10.1177/019263650408864105

Cokley, K. O. (2003). What do we know about the motivation of African American students? Challenging the" anti-intellectual" myth. Harvard Educational Review, 73(4), 524-558

Cuyjet, M. J. (2006). African American men in college. San Francisco: Jossey-Bass.

Dennis, J. M., Phinney, J. S., \& Chuateco, L. I. (2005). The role of motivation, parental support, and peer support in the academic success of ethnic minority first-generation college students. Journal of College Student Development, 46(3), 223-236. http://dx.doi.org/10.1353/csd.2005.0023

Fries-Britt, S., \& Griffin, K. (2007). The Black box: How high-achieving Blacks resist stereotypes about Black Americans. Journal of College Student Development, 48(5), 509-524. http://dx.doi.org/10.1353/csd.2007.0048

Harper, S. R., Carini, R., Bridges, B., \& Hayek, J. (2004). Gender differences in student engagement among African American undergraduates at historically Black colleges and universities. Journal of College Student Development, 45(3), 271-284. http://dx.doi.org/10.1353/csd.2004.0035

Harper, S. R. (2009a). Institutional seriousness concerning Black male student engagement: Necessary conditions and collaborative partnerships. In S. R. Harper \& S. J. Quaye (Eds.). Student engagement in higher education: Theoretical perspectives and practical approaches for diverse populations (pp. 137-156). New York: Routledge.

Harper, S. R. (2009b). Niggers no more: A critical race counter narrative on Black male student achievement at predominantly white colleges and universities. International Journal of Qualitative Studies in Education, 22(6), 697-712. http://dx.doi.org/10.1080/09518390903333889

Harper, S. R. (2012). Black male student success in higher education: A report from the National Black Male College Achievement Study. Philadelphia: University of Pennsylvania, Center for the Study of Race and Equity Education.

Harper, S. R., \& Harris III, F. (2012). Men of Color: A Role for Policymakers in Improving the Status of Black Male Students in US Higher Education. Institute for Higher Education Policy.

Harris, T. L., \& Taylor, G. (2012). Raising African-American Males: Strategies and Interventions for Successful Outcomes. R\&l Education.

Hurtado, S., Egan, M. K., Tran, M. C., Newman, C. B., Chang, M. J., \& Velasco, P. (2011). "We do science here." Underrepresented students' interactions with faculty in different college contexts. Journal of social issues, 67(3), 553-579. http://dx.doi.org/10.1111/j.1540-4560.2011.01714.x

John, E. P. S., Hu, S., Simmons, A., Carter, D. F., \& Weber, J. (2004). What difference does a major make? The influence of college major field on persistence by African American and White students. Research in Higher Education, 45(3), 209-232. http://dx.doi.org/10.1023/B:RIHE.0000019587.46953.9d 
Maton, K. I., \& Hrabowski III, F. A. (2004). Increasing the Number of African American PhDs in the Sciences and Engineering A Strengths-Based Approach. American Psychologist, 59(6), 547. http://dx.doi.org/10.1037/0003-066X.59.6.547

Maxwell, S. E., \& Delaney, H. D. (2004). Designing experiments and analyzing data: A model comparison approach (2nd ed.). Mahwah, NJ: Erlbaum.

Palmer, R. T., \& Gasman, M. (2008). "It takes a village to raise a Child": the role of social capital in promoting academic success for African American men at a black College. Journal of College Student Development, 49(1), 52-70. http://dx.doi.org/10.1353/csd.2008.0002

Palmer, R. T., \& Young, E. M. (2009). Determined to succeed: Salient factors that foster academic success for academically unprepared Black males at a Black college. Journal of College Student Retention, 10(14), 465-482.

Robbins, S. B., Lauver, K., Le, H., Davis, D., Langley, R., \& Carlstrom, A. (2004). Do psychosocial and study skill factors predict college outcomes? A meta-analysis. Psychological bulletin, 130(2), 261. http://dx.doi.org/10.1037/0033-2909.130.2.261

Robbins, S. B., Lauver, K., Le, H., Davis, D., Langley, R., \& Carlstrom, A. (2004). Do psychosocial and study skill factors predict college outcomes? A meta-analysis. Psychological bulletin, 130(2), 261. http://dx.doi.org/10.1037/0033-2909.130.2.261

Ryan, R. M., \& Deci, E. L. (2000). Self-determination theory and the facilitation of intrinsic motivation, social development, and well-being. American Psychologist, 55(1), 68. http://dx.doi.org/10.1037/0003-066X.55.1.68

Saenz, V.B., Hurtado, S., Barrera, D., Walf, D., \& Yeung, F., (2007). First in My Family: A Profile of First-Generation College Students at Four-Year Institutions since 1971. Los Angeles: Higher Education Research Institute, UCLA.

Shrestha, L. B., \& Heisler, E. J. (2011). The Changing Demographic Profile of the United States. Washington D.C.: Diane Publishing

Steele, C. (2003). Stereotype threat and African-American student achievement. Young, gifted, and Black: Promoting high achievement among African-American students, 109-130.

Steele, C. M., \& Aronson, J. A. (2004). Stereotype Threat Does Not Live by Steele and Aronson (1995) Alone.

Strayhorn, T. L. (2008). The role of supportive relationships in facilitating African American males' success in college. NASPA Journal, 45(1), 26-48.

Strayhorn, T. L. (2010). When race and gender collide: Social and cultural capital's influence on the academic achievement of African American and Latino males. The Review of Higher Education, 33(3), 307-332.

Sue, D. W., \& Sue, D. (2012). Counseling the culturally diverse: Theory and practice. Wiley. Com

Toldson, I. A., Sutton, R. M., \& Brown, R. L. F. (2012). Preventing Delinquency and Promoting Academic Success among School-Age African American Males. Journal of African American Males in Education, 3(1), 12-27.

United States Census Bureau. (2012, December 12). U.S. Census Bureau Projections Show a Slower Growing, Older, More Diverse Nation a Half Century from Now. Retrieved February 3, 2013, from Census.gov: http://www.census.gov/newsroom/releases/archives/population/cb12-243.html

U.S. Department of Education. (2011, April). Retrieved March 2012, from United States Department of Education: http://nces.ed.gov/programs/coe/2011/pdf/21_2011.pdf.

U.S. Department of Education, National Center for Education Statistics. (2012). The Condition of Education 2012 (NCES 2012-045).

Weiher, G. R., \& Tedin, K. L. (2006). Minority student achievement. Review of policy research, 23(5), 963-967. http://dx.doi.org/10.1111/j.1541-1338.2006.00244.x

Zimet, G. D., Dahlem, N. W., Zimet, S. G., \& Farley, G. K. (1988). The Multidimensional Scale of Perceived Social Support. Journal Of Personality Assessment, 52(1), 30. http://dx.doi.org/10.1207/s15327752jpa5201_2

\section{(cc) EY}

This work is licensed under a Creative Commons Attribution 3.0 License. 